\title{
Theoretical study on the reactions of $\mathrm{C} 2 \mathrm{H} 5$ with $\mathrm{CnH} 2 \mathrm{n}+1 \mathrm{OH}(\mathrm{n}=1$ - 4): Predicted rate constants and branching ratios
}

\section{Trong-Nghia Nguyen}

Hanoi University of Technology: Hanoi University of Science and Technology

\section{Vu Anh Tuan}

Hanoi University of Technology: Hanoi University of Science and Technology

Phung Thi Viet Bac

Vietnam National University Hanoi

Le Phuoc Anh

Vietnam National University Hanoi

Hue Minh Thi Nguyen ( $\sim$ hue.nguyen@hnue.edu.vn )

Hanoi National University of Education https://orcid.org/0000-0001-6373-4691

\section{Research Article}

Keywords: $\mathrm{C} 2 \mathrm{H} 5, \mathrm{CnH} 2 \mathrm{n}+1 \mathrm{OH}(\mathrm{n}=1-4), \mathrm{B} 3 \mathrm{LYP}, \mathrm{CCSD}(\mathrm{T}), \mathrm{H}$-abstraction, Rate constants

Posted Date: February 17th, 2022

DOI: https://doi.org/10.21203/rs.3.rs-1224120/v1

License: (a) This work is licensed under a Creative Commons Attribution 4.0 International License. Read Full License 


\section{Abstract}

The mechanisms of the reactions of $\mathrm{C}_{2} \mathrm{H}_{5}$ with $\mathrm{C}_{n} \mathrm{H}_{2 n+1} \mathrm{OH}(\mathrm{n}=1-4)$ have been investigated by $\operatorname{CCSD}(T) / / B 3 L Y P / 6-311++G(3 d f, 2 p)$ for $n=1-3$ and $\operatorname{CCSD}(T) / / B 3 L Y P / 6-311+G(d, p)$ for $n=4$. Our chemical quantum results show that the $\mathrm{C}_{2} \mathrm{H}_{5}+\mathrm{CH}_{3} \mathrm{OH}$ reaction can take place via $\mathrm{H}$-abstraction or substitution channels. The former is the major channel with barrier energies of 13.0 and $14.4 \mathrm{kcal} / \mathrm{mol}$ while the latter has to pass over much higher barriers of $42.2-52.3 \mathrm{kcal} / \mathrm{mol}$. Similarly, the $\mathrm{C}_{2} \mathrm{H}_{5}+$ $\mathrm{C}_{n} \mathrm{H}_{2 n+1} \mathrm{OH}(\mathrm{n}=2-4)$ reactions can mainly occur via $\mathrm{H}$-abstraction channels with barrier energies of 10.4 - $16.4 \mathrm{kcal} / \mathrm{mol}$. The b-H abstraction channel has the lowest barrier energy $(11.7 \mathrm{kcal} / \mathrm{mol})$ for $\mathrm{t}-\mathrm{C}_{4} \mathrm{H}_{9} \mathrm{OH}$ while o/a-H abstraction channels have the lowest barrier energies $(10.4-13.0 \mathrm{kcal} / \mathrm{mol})$ for the others. The rate constants and product branching ratios for individual channels as well as total rate constants have been calculated for the temperature range $300-2500 \mathrm{~K}$ by TST theory with Eckart tunneling corrections. The optimized geometries of the related species and predicted heats of reactions agree well with available data.

\section{Introduction}

Alcohol fuels $\left(\mathrm{C}_{n} \mathrm{H}_{2 n+1} \mathrm{OH}, \mathrm{n}=1-4\right)$ are recognized as the most promising renewable energy resources [19]. Methanol $\left(\mathrm{CH}_{3} \mathrm{OH}\right)$ can be used in an internal engine via combustion or in a fuel cell. Ethanol $\left(\mathrm{C}_{2} \mathrm{H}_{5} \mathrm{OH}\right)$ is widely used; a large amount of ethanol is used in gasoline engines as an engine fuel such as E10 (i.e., a fuel blend of $10 \% \mathrm{C}_{2} \mathrm{H}_{5} \mathrm{OH}$ and $90 \%$ gasoline), E15 $\left(15 \% \mathrm{C}_{2} \mathrm{H}_{5} \mathrm{OH}\right)$, E85 $\left(85 \% \mathrm{C}_{2} \mathrm{H}_{5} \mathrm{OH}\right)$, etc. nPropanol $\left(n-\mathrm{C}_{3} \mathrm{H}_{7} \mathrm{OH}\right)$ and isopropanol $\left(\mathrm{i}-\mathrm{C}_{3} \mathrm{H}_{7} \mathrm{OH}\right)$ are potential fuel additives. n-Propanol has a higher heating value than ethanol; isopropanol can readily be used as a fuel for existing engines. Butanols $\left(\mathrm{n} / \mathrm{i} / \mathrm{s} / \mathrm{t}-\mathrm{C}_{4} \mathrm{H}_{9} \mathrm{OH}\right)$ may be second-generation biofuel potential biofuels because they do not suffer from the drawbacks as ethanol does. The favorable characteristics of $\mathrm{C}_{n} \mathrm{H}_{2 n+1} \mathrm{OH}(\mathrm{n}=1-4)$ have led to an increasing number of studies investigating theirs use as a transportation fuel. Specifically, there are many papers concerned $\mathrm{C}_{n} \mathrm{H}_{2 n+1} \mathrm{OH}(\mathrm{n}=1-4)$ such as determining the structure of the molecules, vibrational frequencies, and heats of formation [10-12]; both experimental and theoretical papers concerning thermal decompositions of $\mathrm{C}_{n} \mathrm{H}_{2 n+1} \mathrm{OH}(n=1-4)$ at high-temperatures in the internal engines via combustion [13-19], or their reactions with various atoms and radicals existed in combustion gas, such as $\mathrm{H}, \mathrm{OH}, \mathrm{CH}_{3}$, etc [20-31]. The experimental studies by different techniques report their branching ratio and total rate constants at some specific conditions while the theoretical studies proposed the mechanisms and kinetics results at wide-range conditions, especially experimental difficulty in evaluating the branching fractions mainly arises from the contributions of the secondary reactions. Theoretically, the reactions can occur by various mechanisms including $\mathrm{H}$ - abstraction, insertion, and substitution reactions. For example, in the reactions of $\mathrm{C}_{2} \mathrm{H}_{5} \mathrm{OH}$ with $\mathrm{CH}_{3}$ radical, Lin et al. [21] proposed that the methyl radical can abstract $\mathrm{H}$ atoms in the $\mathrm{OH}, \mathrm{CH}_{2}$, and $\mathrm{CH}_{3}$ groups and substitute $\mathrm{OH}, \mathrm{CH}_{3}$ groups in the $\mathrm{C}_{n} \mathrm{H}_{2 n+1} \mathrm{OH}(\mathrm{n}=1-4)$ molecule. Using the quantum calculations at $\mathrm{G} 2 \mathrm{M}$ level of theory, they concluded that the $\mathrm{H}$ abstraction channels are more favored than the latter. Based on the predicted potential energy 
surface, they calculate rate constants and branching ratios for the $\mathrm{H}$-abstraction reactions; their kinetics results are close to the available experiment.

Besides, ethyl radical $\left(\mathrm{C}_{2} \mathrm{H}_{5}\right)$ is another important free radical in combustion and atmospheric and environmental chemistry [32-34]. Ethyl radical can be formed in the oxidation of natural gas which composes mostly of methane and ethane; for example, ethane can react with $\mathrm{O}_{2}$ giving $\mathrm{C}_{2} \mathrm{H}_{5}$ as [33]: $\mathrm{C}_{2} \mathrm{H}_{6}+\mathrm{O}_{2} \rightarrow \mathrm{C}_{2} \mathrm{H}_{5}+\mathrm{HO}_{2}$. It can also be generated when a large hydrocarbon radical decomposes into smaller radicals including ethyl and methyl radicals. $\mathrm{C}_{2} \mathrm{H}_{5}$ radical is considered as the simplest alkane radicals which can show oxidation features of big alkane radicals [27]. Therefore, its reactions have been attracted much interest, both experimental and theoretical such as reactions of $\mathrm{C}_{2} \mathrm{H}_{5}$ with $\mathrm{O}_{2}, \mathrm{HO}_{2}, \mathrm{NCO}_{\text {, }}$ etc. [34-38].

However, the reactions of $\mathrm{C}_{2} \mathrm{H}_{5}$ with $\mathrm{C}_{n} \mathrm{H}_{2 n+1} \mathrm{OH}(\mathrm{n}=1-4)$ in combustion gas and atmosphere have not been elucidated yet in both mechanisms and kinetics. The present work aims are to elucidate the mechanism for the title reaction through a comprehensive and accurate quantum chemical calculation and to predict the kinetics of individual product channels employing transition state theory with appropriate quantum-mechanical tunneling corrections for combustion applications.

\section{Computation Methods}

All structures involved the $\mathrm{C}_{2} \mathrm{H}_{5}+\mathrm{C}_{n} \mathrm{H}_{2 n+1} \mathrm{OH}(\mathrm{n}=1$ - 4) reactions have been fully optimized by the DFTB3LYP method $[39,40]$ excluding the transition state TS39 (see later) along with 6-311++G(3df,2p) and 6$311+G(d, p)$ basis sets for $n=1-3$ and $n=4$, respectively. Vibrational frequencies predicted at the same level of theory as the optimizations have been used for the rate constant calculations as well as zeropoint energy (ZPE) corrections. They have also been employed for the determination of the optimized structures, in which the reactants $\left(\mathrm{C}_{2} \mathrm{H}_{5}\right.$ and $\left.\mathrm{C}_{n} \mathrm{H}_{2 n+1} \mathrm{OH}(\mathrm{n}=1-4)\right)$ and products possessed all positive vibrational frequencies, whereas each transition state (TS1-TS39) has only one imaginary frequency. To get more reliable energies for all the species, we performed higher-level single-point energy calculations with the $\operatorname{CCSD}(T)$ method $[41,42]$ and the same basis sets based on the B3LYP optimized geometries. The total energy of a species is the sum of the corresponding single-point energy by the CCSD(T) method with the ZPE corrections. All the ab initio calculations have been performed using the Gaussian 09 collection of programs [43].

The rate constants for individual channels of the title reactions have been calculated using the transition state theory (TST) [44] including Eckart tunneling effects [45] in the temperature range of $300-2500 \mathrm{~K}$. In the TST calculations, the $k^{\text {TST }}$ for each channel has been estimated as follows:

$$
\mathrm{k}^{\mathrm{TST}}=\sigma \frac{\mathrm{k}_{\mathrm{B}} T}{h} \frac{Q_{T S}}{N_{A} Q_{A} Q_{B}} \exp \left[-\frac{E_{T S}-E_{A+B}}{k_{B} T}\right]
$$


Where $E_{T S}$ and $E_{A+B}$ are potential energies of the TS (transition state) and $A+B$ (reactants); $Q_{A}, Q_{B}$, and $Q_{T S}$ are partition functions of the $A, B$, and $T S ; \sigma, k_{B}, T, h$, and $N_{A}$ are symmetry number, Boltzmann's constant, the temperature, the Planck's constant, and Avogadro's number, respectively. All the kinetics calculations have been performed with the Multiwell code [46]; the rate constants for individual channels as well as total reactions have been used to fit a modified Arrhenius equation for and presented in Tables 2 and S1 in the electronic supporting information (ESI).

Table 2

Arrhenius parameters $\left[k(T)=A T^{n} e^{-E / R T}\right]$ for the $\mathrm{C}_{2} \mathrm{H}_{5}+\mathrm{C}_{\mathrm{n}} \mathrm{H}_{2 n+1} \mathrm{OH}(\mathrm{n}=1,2)$ reactions.

\begin{tabular}{|c|c|c|c|c|}
\hline Reactions & A & $\mathrm{n}$ & $E$ & $\begin{array}{l}\mathrm{T} \text { - range } \\
(\mathrm{K})\end{array}$ \\
\hline \multicolumn{5}{|l|}{$\mathrm{CH}_{3} \mathrm{OH}$} \\
\hline $\mathrm{C}_{2} \mathrm{H}_{5}+\mathrm{CH}_{3} \mathrm{OH} \rightarrow \mathrm{CH}_{3} \mathrm{O}+\mathrm{C}_{2} \mathrm{H}_{6}$ & $7.37 \cdot 10^{36}$ & 7.07 & -2915.1 & $300-600$ \\
\hline $\mathrm{C}_{2} \mathrm{H}_{5}+\mathrm{CH}_{3} \mathrm{OH} \rightarrow \mathrm{CH}_{3} \mathrm{O}+\mathrm{C}_{2} \mathrm{H}_{6}$ & $1.93 \cdot 10^{24}$ & 3.51 & -5084.1 & $600-2500$ \\
\hline $\mathrm{C}_{2} \mathrm{H}_{5}+\mathrm{CH}_{3} \mathrm{OH} \rightarrow \mathrm{CH}_{2} \mathrm{OH}+\mathrm{C}_{2} \mathrm{H}_{6}$ & $7.58 \cdot 10^{50}$ & 11.57 & -1101.3 & $300-600$ \\
\hline $\mathrm{C}_{2} \mathrm{H}_{5}+\mathrm{CH}_{3} \mathrm{OH} \rightarrow \mathrm{CH}_{2} \mathrm{OH}+\mathrm{C}_{2} \mathrm{H}_{6}$ & $1.35 \cdot 10^{25}$ & 3.97 & -5503.5 & $600-2500$ \\
\hline $\mathrm{C}_{2} \mathrm{H}_{5}+\mathrm{CH}_{3} \mathrm{OH} \rightarrow$ Products & $1.31 \cdot 10^{40}$ & 8.69 & -2264.4 & $300-600$ \\
\hline $\mathrm{C}_{2} \mathrm{H}_{5}+\mathrm{CH}_{3} \mathrm{OH} \rightarrow$ Products & $2.11 \cdot 10^{25}$ & 3.94 & -5105.8 & $600-2500$ \\
\hline \multicolumn{5}{|l|}{$\mathrm{C}_{2} \mathrm{H}_{5} \mathrm{OH}$} \\
\hline $\mathrm{C}_{2} \mathrm{H}_{5}+\mathrm{C}_{2} \mathrm{H}_{5} \mathrm{OH} \rightarrow \mathrm{C}_{2} \mathrm{H}_{5} \mathrm{O}+\mathrm{C}_{2} \mathrm{H}_{6}$ & $1.33 \cdot 10^{33}$ & 6.44 & -3182.3 & $300-600$ \\
\hline $\mathrm{C}_{2} \mathrm{H}_{5}+\mathrm{C}_{2} \mathrm{H}_{5} \mathrm{OH} \rightarrow \mathrm{C}_{2} \mathrm{H}_{5} \mathrm{O}+\mathrm{C}_{2} \mathrm{H}_{6}$ & $1.33 \cdot 10^{23}$ & 3.31 & -4987.8 & $600-2500$ \\
\hline $\mathrm{C}_{2} \mathrm{H}_{5}+\mathrm{C}_{2} \mathrm{H}_{5} \mathrm{OH} \rightarrow \mathrm{CH}_{3} \mathrm{CHOH}+\mathrm{C}_{2} \mathrm{H}_{6}$ & $4.20 \cdot 10^{46}$ & 10.36 & -1073.8 & $300-600$ \\
\hline $\mathrm{C}_{2} \mathrm{H}_{5}+\mathrm{C}_{2} \mathrm{H}_{5} \mathrm{OH} \rightarrow \mathrm{CH}_{3} \mathrm{CHOH}+\mathrm{C}_{2} \mathrm{H}_{6}$ & $4.07 \cdot 10^{24}$ & 3.50 & -5151.5 & $600-2500$ \\
\hline $\mathrm{C}_{2} \mathrm{H}_{5}+\mathrm{C}_{2} \mathrm{H}_{5} \mathrm{OH} \rightarrow \mathrm{CH}_{2} \mathrm{CH}_{2} \mathrm{OH}+\mathrm{C}_{2} \mathrm{H}_{6}$ & $3.98 \cdot 10^{47}$ & 10.76 & -2842.3 & $300-600$ \\
\hline $\mathrm{C}_{2} \mathrm{H}_{5}+\mathrm{C}_{2} \mathrm{H}_{5} \mathrm{OH} \rightarrow \mathrm{CH}_{2} \mathrm{CH}_{2} \mathrm{OH}+\mathrm{C}_{2} \mathrm{H}_{6}$ & $1.42 \cdot 10^{24}$ & 3.69 & -6935.4 & $600-2500$ \\
\hline $\mathrm{C}_{2} \mathrm{H}_{5}+\mathrm{C}_{2} \mathrm{H}_{5} \mathrm{OH} \rightarrow$ Products & $4.15 \cdot 10^{41}$ & 8.91 & -1908.1 & $300-600$ \\
\hline $\mathrm{C}_{2} \mathrm{H}_{5}+\mathrm{C}_{2} \mathrm{H}_{5} \mathrm{OH} \rightarrow$ Products & $6.52 \cdot 10^{25}$ & 3.84 & -4845.1 & $600-250$ \\
\hline
\end{tabular}

\section{Results And Discussion}




\subsection{Potential energy surfaces and reaction mechanisms}

The geometries of the reactants and products for the $\mathrm{C}_{2} \mathrm{H}_{5}$ and $n-\mathrm{C}_{n} \mathrm{H}_{2 n+1} \mathrm{OH}(\mathrm{n}=1-4)$ reactions are shown in Figs. 1 (for $n=1,2$ ) and $S 1$ (for $n=3,4$ ) in the ESl; those of the transition states are in Figs. 2 (for $n=1,2$ ) and $S 2$ (for $n=3,4$ ). The potential energy surfaces for the title reactions are shown in Figs. 3 (for $n=1,2$ ) and S3 (for $n=3,4$ ) in the ESI, and heats of reaction for the $C_{2} H_{5}+C_{n} H_{2 n+1} O H(n=1,2)$ reactions are shown in Table 1. 
Table 1

Comparison of Heats of reaction for the $\mathrm{C}_{2} \mathrm{H}_{5}+\mathrm{C}_{n} \mathrm{H}_{2 n+1} \mathrm{OH}(\mathrm{n}=1,2)$ reactions calculated at the $\operatorname{CCSD}(\mathrm{T}) / / \mathrm{B} 3 \mathrm{LYP} / 6-311++\mathrm{G}(3 \mathrm{df}, 2 \mathrm{p})$ level of theory with available data [54-58].

\begin{tabular}{|c|c|c|c|c|}
\hline \multirow[t]{2}{*}{ Reactions } & \multicolumn{2}{|c|}{$\Delta_{\mathrm{r}} H_{0}(\mathrm{kcal} / \mathrm{mol})$} & \multicolumn{2}{|c|}{$\Delta_{\mathrm{r}} H_{298}(\mathrm{kcal} / \mathrm{mol})$} \\
\hline & Predicted & Literature* & Predicted & Literature* \\
\hline \multicolumn{5}{|l|}{$\mathrm{CH}_{3} \mathrm{OH}+\mathrm{C}_{2} \mathrm{H}_{5}$} \\
\hline PR1 $\left(\mathrm{CH}_{3} \mathrm{O}+\mathrm{C}_{2} \mathrm{H}_{6}\right)$ & 3.2 & $4.4 \pm 1.1$ & 2.7 & $4.1 \pm 1.1$ \\
\hline PR2 $\left(\mathrm{CH}_{2} \mathrm{OH}+\mathrm{C}_{2} \mathrm{H}_{6}\right)$ & -4.6 & $-5.0 \pm 0.8$ & -4.9 & $-5.0 \pm 0.8$ \\
\hline PR3 $\left(\mathrm{CH}_{3} \mathrm{OC}_{2} \mathrm{H}_{5}+\mathrm{H}\right)$ & 17.7 & $19.3 \pm 0.6$ & 17.4 & $19.5 \pm 0.6$ \\
\hline PR4 $\left(\mathrm{C}_{2} \mathrm{H}_{5} \mathrm{OH}+\mathrm{CH}_{3}\right)$ & -2.4 & $-2.1 \pm 0.7$ & -2.4 & $-1.9 \pm 0.7$ \\
\hline PR5 $\left(\mathrm{C}_{3} \mathrm{H}_{8}+\mathrm{OH}\right)$ & 3.1 & $3.1 \pm 0.7$ & 2.8 & $3.1 \pm 0.7$ \\
\hline PR6 $\left(n-C_{3} \mathrm{H}_{7} \mathrm{OH}+\mathrm{H}\right)$ & 9.8 & $10.3 \pm 0.6$ & 9.6 & $10.3 \pm 0.6$ \\
\hline \multicolumn{5}{|l|}{$\mathrm{C}_{2} \mathrm{H}_{5} \mathrm{OH}+\mathrm{C}_{2} \mathrm{H}_{5}$} \\
\hline $\mathrm{PR7}\left(\mathrm{C}_{2} \mathrm{H}_{5} \mathrm{O}+\mathrm{C}_{2} \mathrm{H}_{6}\right)$ & 3.0 & $4.0 \pm 2.1$ & 2.8 & $3.9 \pm 2.1$ \\
\hline PR8 $\left(\mathrm{CH}_{3} \mathrm{CHOH}+\mathrm{C}_{2} \mathrm{H}_{6}\right)$ & -5.8 & - & -6.1 & - \\
\hline PR9 $\left(\mathrm{CH}_{2} \mathrm{CH}_{2} \mathrm{OH}+\mathrm{C}_{2} \mathrm{H}_{6}\right)$ & 1.5 & - & 1.5 & - \\
\hline $\operatorname{PR} 10\left(\mathrm{C}_{2} \mathrm{H}_{5} \mathrm{OC}_{2} \mathrm{H}_{5}+\mathrm{H}\right)$ & 17.3 & $18.6 \pm 1.1$ & 17.3 & $19.4 \pm 1.1$ \\
\hline $\operatorname{PR} 11\left(\mathrm{C}_{2} \mathrm{H}_{5} \mathrm{OH}+\mathrm{C}_{2} \mathrm{H}_{5}\right)$ & 0.0 & 0.0 & 0.0 & 0.0 \\
\hline $\mathrm{PR} 12\left(\mathrm{n}-\mathrm{C}_{4} \mathrm{H}_{10}+\mathrm{OH}\right)$ & 5.8 & $5.7 \pm 1.3$ & 5.7 & $6.1 \pm 1.3$ \\
\hline PR13 $\left(\mathrm{s}-\mathrm{C}_{4} \mathrm{H}_{9} \mathrm{OH}+\mathrm{H}\right)$ & 8.0 & - & 7.9 & - \\
\hline PR14 $\left(n-\mathrm{C}_{4} \mathrm{H}_{9} \mathrm{OH}+\mathrm{H}\right)$ & 12.5 & -- & 12.5 & - \\
\hline $\operatorname{PR} 15\left(\mathrm{C}_{3} \mathrm{H}_{8}+\mathrm{CH}_{2} \mathrm{OH}\right)$ & -1.6 & $-1.9 \pm 1.3$ & -1.9 & $-1.9 \pm 1.3$ \\
\hline $\operatorname{PR} 16\left(\mathrm{n}-\mathrm{C}_{3} \mathrm{H}_{7} \mathrm{OH}+\mathrm{CH}_{3}\right)$ & 0.6 & $1.0 \pm 1.1$ & 0.8 & $1.3 \pm 1.1$ \\
\hline
\end{tabular}

The reaction of $\mathrm{C}_{2} \mathrm{H}_{5}+\mathrm{CH}_{3} \mathrm{OH}$ : 
The PES in Figure 1a reveals that the $\mathrm{C}_{2} \mathrm{H}_{5}$ radical can abstract $\mathrm{H}$ atoms in the $\mathrm{OH}$ and $\mathrm{CH}_{3}$ groups giving PR1 $\left(\mathrm{CH}_{3} \mathrm{O}+\mathrm{C}_{2} \mathrm{H}_{6}\right)$ and PR2 $\left(\mathrm{CH}_{2} \mathrm{OH}+\mathrm{C}_{2} \mathrm{H}_{6}\right)$, or substitute atoms and groups such as $\mathrm{H}, \mathrm{OH}, \mathrm{CH}_{3}$ in the $\mathrm{CH}_{3} \mathrm{OH}$ molecule giving PR3 $\left(\mathrm{CH}_{3} \mathrm{OC}_{2} \mathrm{H}_{5}+\mathrm{H}\right)-\mathrm{PR} 6\left(\mathrm{n}-\mathrm{C}_{3} \mathrm{H}_{7} \mathrm{OH}+\mathrm{H}\right)$. The substitution channels should be very minor because of having significantly higher barrier energies of $\sim 30 \mathrm{kcal} / \mathrm{mol}$.

Formation of PR1 $\left(\mathrm{CH}_{3} \mathrm{O}+\mathrm{C}_{2} \mathrm{H}_{6}\right)$ and PR2 $\left(\mathrm{CH}_{2} \mathrm{OH}+\mathrm{C}_{2} \mathrm{H}_{6}\right)$ :

These channels can occur from $\mathrm{CH}_{3} \mathrm{OH}$ when the $\mathrm{C}_{2} \mathrm{H}_{5}$ radical abstracts $\mathrm{H}$ atoms in the $\mathrm{OH}$, and $\mathrm{CH}_{3}$ groups via TS1 $\left(\mathrm{C}_{2} \mathrm{H}_{5} \ldots \mathrm{H}_{\ldots} . . \mathrm{OCH}_{3}\right)$ and TS2 $\left(\mathrm{C}_{2} \mathrm{H}_{5} \ldots \mathrm{H} \ldots \mathrm{CH}_{2} \mathrm{OH}\right)$ giving PR1 $\left(\mathrm{CH}_{3} \mathrm{O}+\mathrm{C}_{2} \mathrm{H}_{6}\right)$ and PR2 $\left(\mathrm{CH}_{2} \mathrm{OH}\right.$ $+\mathrm{C}_{2} \mathrm{H}_{6}$ ), respectively, as clearly shown in Fig. 1. The geometries of $\mathrm{CH}_{3} \mathrm{OH}, \mathrm{C}_{2} \mathrm{H}_{6}$, and $\mathrm{CH}_{3} \mathrm{O}$ optimized at the $B 3 L Y P / 6-311++G(3 d f, 2 p)$ level agree well with the experimental values (see Fig. 1). For example, the $\mathrm{O}-\mathrm{H}, \mathrm{C}-\mathrm{O}$, and $\mathrm{C}-\mathrm{H}$ bond length of $\mathrm{CH}_{3} \mathrm{OH}$ computed in this work are $0.960,1.421$, and $1.088 \AA$, which is in good agreement with the experimental value of $0.956,1.427$, and $1.096 \AA$, respectively [10]. For the transition states TS1 and TS2, there are no experimental results but their geometries agree well with the previous theoretical studies. For example, the length of the broken $\mathrm{O} . . . \mathrm{H}$ bond in TS1 calculated in this work, $1.253 \AA$, is close to $1.2479 \AA$ for the $\mathrm{CH}_{3}+\mathrm{CH}_{3} \mathrm{OH}$ reaction by Jodkowski et al.[25] The imaginary frequencies are $1524 i \mathrm{~cm}^{-1}$ for TS1 and $1715 i \mathrm{~cm}^{-1}$ for TS2 computed at the B3LYP/6-311++G(3df,2p) level corresponding migrations of the $\mathrm{H}$ atoms from $\mathrm{O}$ and $\mathrm{C}$ of the $\mathrm{CH}_{3} \mathrm{OH}$ molecule to the $\mathrm{C}_{2} \mathrm{H}_{5}$ radical. The relative energies for TS1 and TS2 predicted at the CCSD $(T) / / B 3 L Y P / 6-311++G(3 d f, 2 p)$ level of theory in this work are 13.0 and $14.4 \mathrm{kcal} / \mathrm{mol}$ which are in good agreement with 13.6 and $14.0 \mathrm{kcal} / \mathrm{mol}$, respectively, corresponding to the barrier energies for $\mathrm{H}$-abstractions of the $\mathrm{CH}_{3}+\mathrm{CH}_{3} \mathrm{OH}$ reaction calculated at the $\mathrm{G} 2$ level of theory reported by Jodkowski et al. [25]. In addition, we have also compared the predicted heats of reaction $\left(\Delta_{\mathrm{r}} H^{\circ}\right)$ for the channels with available experimental data at both 0 and 298 $\mathrm{K}$ (see Table 1). The heat of formation for each channel is evaluated with the heats of formation of $\mathrm{CH}_{3} \mathrm{OH}(-190,12 \pm 0,6 \mathrm{~kJ} / \mathrm{mol}), \mathrm{C}_{2} \mathrm{H}_{5}, \mathrm{CH}_{3} \mathrm{O}(28,4 \pm 2,1 \mathrm{~kJ} / \mathrm{mol}), \mathrm{CH}_{2} \mathrm{OH}(-10,7 \pm 0,7 \mathrm{~kJ} / \mathrm{mol})$ and $\mathrm{C}_{2} \mathrm{H}_{6}$ $(-68,38 \pm 0,4 \mathrm{~kJ} / \mathrm{mol})$ species from the available experimental data [54-57]. The heats of reaction for channels giving the PR1 and PR2 predicted at the $\operatorname{CCSD}(T) / / B 3 L Y P / 6-311++G(3 d f, 2 p)$ level to be 3.2 and $-4.6 \mathrm{kcal} / \mathrm{mol}$ at $0 \mathrm{~K} ; 2.7$ and $-4.9 \mathrm{kcal} / \mathrm{mol}$ at $298 \mathrm{~K}$, respectively. These values are in good agreement with the experimental values of $4.4 \pm 1.1$ and $-5.0 \pm 0.8 \mathrm{kcal} / \mathrm{mol}$ at $0 \mathrm{~K}$ and $4.1 \pm 1.1$ and $-5.0 \pm 0.8$ $\mathrm{kcal} / \mathrm{mol}$ at $298 \mathrm{~K}$, respectively.

Formation of PR3 $\left(\mathrm{CH}_{3} \mathrm{OC}_{2} \mathrm{H}_{5}+\mathrm{H}\right), \mathrm{PR} 4\left(\mathrm{C}_{2} \mathrm{H}_{5} \mathrm{OH}+\mathrm{CH}_{3}\right), \mathrm{PR} 5\left(\mathrm{C}_{3} \mathrm{H}_{8}+\mathrm{OH}\right)$, and PR6 $\left(n-\mathrm{C}_{3} \mathrm{H}_{7} \mathrm{OH}+\mathrm{H}\right)$ :

The products can be formed when the $\mathrm{C}_{2} \mathrm{H}_{5}$ radical substitutes the $\mathrm{H}$ atoms, $\mathrm{OH}$, and $\mathrm{CH}_{3}$ groups in the $\mathrm{CH}_{3} \mathrm{OH}$ molecule via TS3, TS4, TS5, and TS6, respectively (see Fig. 1a). The geometries of these transition states are also close to those in the previous studies. For example, the length of the breaking $\left(\mathrm{C}_{2} \mathrm{H}_{5} \ldots \mathrm{O}\right)$ and forming $\left(\mathrm{CH}_{3} \ldots \mathrm{O}\right)$ bond lengths of TS4 in this work, 1.845 and $1.860 \AA$, are close to 1.847 and $1.862 \AA$ for the $\mathrm{CH}_{3}+\mathrm{C}_{2} \mathrm{H}_{5} \mathrm{OH}$ by Lin et al. [21]. Our predicted heats of reaction for channels giving the PR3, PR4, PR5 and PR6, 17.7, -2.4, 3.1 and $9.8 \mathrm{kcal} / \mathrm{mol}$ at $0 \mathrm{~K} ; 17.4,-2.4,2.8$ and $9.6 \mathrm{kcal} / \mathrm{mol}$ at 298 $\mathrm{K}$, respectively, are reasonable agreement with the experimental values of $19.3 \pm 0.6,-2.1 \pm 0.7,3.1 \pm 0.7$ 
and $10.3 \pm 0.6 \mathrm{kcal} / \mathrm{mol}$ at $0 \mathrm{~K} ; 19.5 \pm 0.6,-1.9 \pm 0.7,3.1 \pm 0.7$ and $10.3 \pm 0.6 \mathrm{kcal} / \mathrm{mol}$ at $298 \mathrm{~K}$, respectively (see Table 1). It is noticed that these barrier energies (TS3 - TS6) are much higher (> 27 $\mathrm{kcal} / \mathrm{mol}$ ) than those for the $\mathrm{H}$-abstractions (TS1 and TS2); this picture agrees with the results for the $\mathrm{CH}_{3}$ $+\mathrm{C}_{2} \mathrm{H}_{5} \mathrm{OH}$ reaction by Lin et al. [21]. It is obvious that the channels giving PR3 - PR6 should be kinetically unimportant because of having very high barrier energies at TS3 - TS6.

The reaction of $\mathrm{C}_{2} \mathrm{H}_{5}+\mathrm{C}_{2} \mathrm{H}_{5} \mathrm{OH}$ :

Figure $1 \mathrm{~b}$ reveals that the $\mathrm{C}_{2} \mathrm{H}_{5}$ radical can abstract $\mathrm{H}$ atoms in the $\mathrm{OH}, \mathrm{CH}_{2}$, and $\mathrm{CH}_{3}$ groups giving PR7 $\left(\mathrm{C}_{2} \mathrm{H}_{5} \mathrm{O}+\mathrm{C}_{2} \mathrm{H}_{6}, 3.0 \mathrm{kcal} / \mathrm{mol}\right)$, PR8 $\left(\mathrm{CH}_{3} \mathrm{CHOH}+\mathrm{C}_{2} \mathrm{H}_{6},-5.5 \mathrm{kcal} / \mathrm{mol}\right)$, and PR9 $\left(\mathrm{CH}_{2} \mathrm{CH}_{2} \mathrm{OH}+\mathrm{C}_{2} \mathrm{H}_{6}, 1.5\right.$ $\mathrm{kcal} / \mathrm{mol}$ ) via transition states at TS7, TS8, and TS9, respectively. The geometries of the ethanol molecule and transition states predicted at the B3LYP/6-311++G(3df,2p) level of theory agree well with the previous studies (see Figures 1 and 2). For example, in the TS7 - TS9, the broken $0 . . . \mathrm{H}, \mathrm{C} . . \mathrm{H}$ (in $\mathrm{CH}_{2}$ group), and $\mathrm{C} . . . \mathrm{H}$ (in $\mathrm{CH}_{3}$ group) are elongated by $31 \%, 21 \%$, and $25 \%$ while the corresponding values for the $\mathrm{CH}_{3}+$ $\mathrm{C}_{2} \mathrm{H}_{5} \mathrm{OH}$ reaction are $26 \%, 17 \%$, and $22 \%$, respectively by Lin et al. [21]. The relative energies of TS7 (13.0 $\mathrm{kcal} / \mathrm{mol})$, TS8 $(12.6 \mathrm{kcal} / \mathrm{mol})$, and TS $8(16.7 \mathrm{kcal} / \mathrm{mol})$ are close to the corresponding values of 13.2 , 12.0 , and $16.0 \mathrm{kcal} / \mathrm{mol}$ for the $\mathrm{CH}_{3}+\mathrm{C}_{2} \mathrm{H}_{5} \mathrm{OH}$ reaction predicted at the $\mathrm{G} 2 \mathrm{M}(\mathrm{RCC} 2)$ level of theory. It is noticed that among $\mathrm{H}$ - abstractions of the $\mathrm{o}-\mathrm{H}$ (OH group), $\mathrm{a}-\mathrm{H}\left(\mathrm{CH}_{2}\right.$ group), and $\beta-\mathrm{H}\left(\mathrm{CH}_{3}\right.$ group), the last channel has higher barrier energy of about $3.7 \mathrm{kcal} / \mathrm{mol}$ suggesting that this channel has a small contribution at the normal temperature. This picture is also in reasonable agreement with the result of Lin et al for the $\mathrm{CH}_{3}+\mathrm{C}_{2} \mathrm{H}_{5} \mathrm{OH}$ reaction [21]. In addition, the $\mathrm{C}_{2} \mathrm{H}_{5}$ radical can substitute $\mathrm{H}$ atom and $\mathrm{OH}, \mathrm{CH}_{3}$, and $\mathrm{C}_{2} \mathrm{H}_{5}$ groups in the $\mathrm{C}_{2} \mathrm{H}_{5} \mathrm{OH}$ molecule via transition states at TS10 - TS16 giving PR10 $\left(\mathrm{C}_{2} \mathrm{H}_{5} \mathrm{OC}_{2} \mathrm{H}_{5}\right.$ $+\mathrm{H})-\mathrm{PR} 16\left(\mathrm{n}-\mathrm{C}_{4} \mathrm{H}_{9} \mathrm{OH}+\mathrm{CH}_{3}\right)$. However, these substitution channels are unfavorable on account of the high barriers at the TS10 - TS16 $(41.5-57.0 \mathrm{kcal} / \mathrm{mol})$ (see Figure 3b).

The reaction of $\mathrm{C}_{2} \mathrm{H}_{5}+\mathrm{n} / \mathrm{i}-\mathrm{C}_{3} \mathrm{H}_{7} \mathrm{OH}$ :

For the $\mathrm{C}_{2} \mathrm{H}_{5}+\mathrm{n}-\mathrm{C}_{3} \mathrm{H}_{7} \mathrm{OH}$ system, there are four reaction channels as clearly shown in Figure S2a: the $\mathrm{C}_{2} \mathrm{H}_{5}$ radical can abstract o- $\mathrm{H}$ (in the $\mathrm{OH}$ group), $\mathrm{a}-\mathrm{H}$ (in the $\mathrm{CH}_{2}$ group), $\beta-\mathrm{H}$ (in the $\mathrm{CH}_{2}$ group) or $\mathrm{\gamma}-\mathrm{H}$ (in the $\mathrm{CH}_{3}$ group) giving PR17 ( $\left.\mathrm{n}-\mathrm{C}_{3} \mathrm{H}_{7} \mathrm{O}+\mathrm{C}_{2} \mathrm{H}_{6}, 3.0 \mathrm{kcal} / \mathrm{mol}\right)$, PR18 $\left(\mathrm{CH}_{3} \mathrm{CH}_{2} \mathrm{CHOH}+\mathrm{C}_{2} \mathrm{H}_{6},-5.4 \mathrm{kcal} / \mathrm{mol}\right)$, PR19 $\left(\mathrm{CH}_{3} \mathrm{CHCH}_{2} \mathrm{OH}+\mathrm{C}_{2} \mathrm{H}_{6},-1.2 \mathrm{kcal} / \mathrm{mol}\right)$, and PR2O $\left(\mathrm{CH}_{2} \mathrm{CH}_{2} \mathrm{CH}_{2} \mathrm{OH}+\mathrm{C}_{2} \mathrm{H}_{6}, 0.4 \mathrm{kcal} / \mathrm{mol}\right)$ via transition states TS17, TS18, TS19, and TS20, respectively. Figure S2a also shows that among the energy barriers, the value of TS18 corresponding to the $\mathrm{a}-\mathrm{H}$ abstraction is lowest with an activation energy of $12.1 \mathrm{kcal} / \mathrm{mol}$ compared to $12.9 \mathrm{kcal} / \mathrm{mol}$ at TS18 (for o-H abstraction), $14.0 \mathrm{kcal} / \mathrm{mol}$ at TS19 (for $\mathrm{y}-\mathrm{H}$ abstraction) and $15.8 \mathrm{kcal} / \mathrm{mol}$ at TS20 (for $\delta-\mathrm{H}$ abstraction) suggesting the $\mathrm{a}-\mathrm{H}$ abstraction is the major channel for the $\mathrm{C}_{2} \mathrm{H}_{5}+\mathrm{n}-\mathrm{C}_{3} \mathrm{H}_{7} \mathrm{OH}$ reaction. For $\mathrm{C}_{2} \mathrm{H}_{5}+\mathrm{i}-\mathrm{C}_{3} \mathrm{H}_{7} \mathrm{OH}$ reaction, the $\mathrm{C}_{2} \mathrm{H}_{5}$ radical can abstract o$\mathrm{H}$ (in the $\mathrm{OH}$ group), $\mathrm{a}-\mathrm{H}$ (in the $\mathrm{CH}$ group), $\beta-\mathrm{H}$ (in the $\mathrm{CH}_{3}$ groups) giving PR21 (i- $\mathrm{C}_{3} \mathrm{H}_{7} \mathrm{O}+\mathrm{C}_{2} \mathrm{H}_{6}, 4.8$ $\mathrm{kcal} / \mathrm{mol})$, PR22 $\left(\mathrm{CH}_{3} \mathrm{C}\left(\mathrm{CH}_{3}\right) \mathrm{OH}+\mathrm{C}_{2} \mathrm{H}_{6},-6.6 \mathrm{kcal} / \mathrm{mol}\right)$ and PR23 $\left(\mathrm{CH}_{2} \mathrm{CH}\left(\mathrm{CH}_{3}\right) \mathrm{OH}+\mathrm{C}_{2} \mathrm{H}_{6}, 1.9 \mathrm{kcal} / \mathrm{mol}\right)$ via TS21, TS22, and TS23, respectively (see Figure S2b). It is noticed that the energy barrier for the a-H 
abstraction (TS21) is only $10.4 \mathrm{kcal} / \mathrm{mol}$ which is the lowest energy barrier among the $\mathrm{C}_{2} \mathrm{H}_{5}+\mathrm{C}_{n} \mathrm{H}_{2 n+1} \mathrm{OH}$ $(n=1-4)$ reactions because of the effect of the two $\mathrm{CH}_{3}$ groups and $\mathrm{OH}$ group in $\mathrm{i}-\mathrm{C}_{3} \mathrm{H}_{7} \mathrm{OH}$ molecule. This barrier is also lower $\sim 2-6 \mathrm{kcal} / \mathrm{mol}$ than the others at TS22 $(12.7 \mathrm{kcal} / \mathrm{mol})$ and TS23 $(16.4$ $\mathrm{kcal} / \mathrm{mol}$ ) suggesting that the $\mathrm{a}-\mathrm{H}$ abstraction channel should be the major channel in the $\mathrm{C}_{2} \mathrm{H}_{5}+\mathrm{i}-$ $\mathrm{C}_{3} \mathrm{H}_{7} \mathrm{OH}$ reaction.

The reaction of $\mathrm{C}_{2} \mathrm{H}_{5}+\mathrm{n} / \mathrm{i} / \mathrm{s} / \mathrm{t}-\mathrm{C}_{4} \mathrm{H}_{9} \mathrm{OH}$ :

For the $\mathrm{C}_{2} \mathrm{H}_{5}+\mathrm{n} / \mathrm{i} / \mathrm{s} / \mathrm{t}-\mathrm{C}_{4} \mathrm{H}_{9} \mathrm{OH}$ systems, we calculate with a smaller basic set at the CCSD(T)//B3LYP/6$311+G(d, p)$ level of theory because of their large systems. For the $\mathrm{C}_{2} \mathrm{H}_{5}+\mathrm{t}-\mathrm{C}_{4} \mathrm{H}_{9} \mathrm{OH}$ reaction, Figure S2 shows that there are two channels including $\mathrm{o}-\mathrm{H}$ and $\beta-\mathrm{H}$ abstractions in which the former has lower barrier energy of 12.8 (TS38) than that of $15.4 \mathrm{kcal} / \mathrm{mol}$ (TS39) for the latter. The barrier energy for o-H abstraction channel $(12.8 \mathrm{kcal} / \mathrm{mol})$ for the $\mathrm{C}_{2} \mathrm{H}_{5}+\mathrm{t}-\mathrm{C}_{4} \mathrm{H}_{9} \mathrm{OH}$ reaction predicted the $\operatorname{CCSD}(T) / / B 3 L Y P / 6-311+G(d, p)$ level of theory agree well with those of 12.9 and $13.0 \mathrm{kcal} / \mathrm{mol}$ for the $\mathrm{C}_{2} \mathrm{H}_{5}+\mathrm{C}_{n} \mathrm{H}_{2 n+1} \mathrm{OH}(\mathrm{n}=2,3)$ reactions, respectively, predicted at the CCSD (T)//B3LYP/6-311++G (3df,2p) level of theory. The barrier energy of the $\mathrm{H}$ abstraction from the $\mathrm{CH}_{3}$ group for the $\mathrm{t}-\mathrm{C}_{4} \mathrm{H}_{9} \mathrm{OH}$ (TS39, 15.4 $\mathrm{kcal} / \mathrm{mol}$ ) also agrees well with those for $\mathrm{n} / \mathrm{i} / \mathrm{s}-\mathrm{C}_{4} \mathrm{H}_{9} \mathrm{OH}$ with the values of $15.6-16.0 \mathrm{kcal} / \mathrm{mol}$ (see Fig. $3 \mathrm{~S}$ in the ESI). It is noticed that TS39 is the unique species in the title reactions optimized at the $B$ HandHLYP/6-311+G(d,p) level because we cannot find it at the B3LYP/6-311+G(d,p) level of theory. Its relative energy, therefore, is calculated from energies of TS39, $t-\mathrm{C}_{4} \mathrm{H}_{9} \mathrm{OH}$, and $\mathrm{C}_{2} \mathrm{H}_{5}$ species at the $\operatorname{CCSD}(\mathrm{T}) / / \mathrm{BH}$ andHLYP/6-311+G(d,p) level. The $\mathrm{C}_{2} \mathrm{H}_{5}+\mathrm{i}-\mathrm{C}_{4} \mathrm{H}_{9} \mathrm{OH}$ reaction has four channels including o$\mathrm{H}, \mathrm{a}-\mathrm{H}, \beta-\mathrm{H}$, and $\mathrm{\gamma}-\mathrm{H}$ abstractions in which the lowest energy barrier is the $\beta-\mathrm{H}$ abstraction (TS31, 11.7 $\mathrm{kcal} / \mathrm{mol}$ ) because of the effect of the two $\mathrm{CH}_{3}$ groups in the $\mathrm{i}-\mathrm{C}_{4} \mathrm{H}_{9} \mathrm{OH}$ molecule. Energy barriers for the o$\mathrm{H}, \mathrm{a}-\mathrm{H}$, and $\mathrm{\gamma}-\mathrm{H}$ abstraction channels in the $\mathrm{C}_{2} \mathrm{H}_{5}+\mathrm{i}-\mathrm{C}_{4} \mathrm{H}_{9} \mathrm{OH}$ reaction, $12.6,12.3$, and $15.6 \mathrm{kcal} / \mathrm{mol}$ at TS29, TS30, and TS32, respectively, also agree well with the corresponding values at 12.9, 12.1, and 15.8 $\mathrm{kcal} / \mathrm{mol}$ for $\mathrm{n}-\mathrm{C}_{3} \mathrm{H}_{7} \mathrm{OH}+\mathrm{C}_{2} \mathrm{H}_{5}$ reaction as discussed above. For the reactions of the $\mathrm{C}_{2} \mathrm{H}_{5}$ radical with $\mathrm{n} / \mathrm{s}-\mathrm{C}_{4} \mathrm{H}_{9} \mathrm{OH}$, Figure $\mathrm{S} 2$ shows that there are five channels in which the $\mathrm{o}-\mathrm{H}$ and $\mathrm{a}-\mathrm{H}$ abstraction channels have lowest the barrier energies. The o- $\mathrm{H}$ abstractions occur via TS24 and TS33 lying 12.6 above the reactants for both $\mathrm{n}-\mathrm{C}_{4} \mathrm{H}_{9} \mathrm{OH}$ and s- $\mathrm{C}_{4} \mathrm{H}_{9} \mathrm{OH}$, respectively. The a-H abstractions are slightly lower than those for o- $\mathrm{H}$ abstractions with relative energies of 11.9 and $11.0 \mathrm{kcal} / \mathrm{mol}$ for $\mathrm{n}-\mathrm{C}_{4} \mathrm{H}_{9} \mathrm{OH}$ and s- $\mathrm{C}_{4} \mathrm{H}_{9} \mathrm{OH}$, respectively while the values for the other channels are $13.8-16.0 \mathrm{kcal} / \mathrm{mol}$. It is clear that the difference between the barrier energies is small suggesting that all of the channels can contribute at high temperatures.

\subsection{Rate constant calculations}

Based on the PES and molecular parameters of all the related species in the $\mathrm{C}_{2} \mathrm{H}_{5}+\mathrm{C}_{n} \mathrm{H}_{2 n+1} \mathrm{OH}(\mathrm{n}=1-4)$ reactions calculated by both the $\operatorname{CCSD}(T)$ and B3LYP methods as discussed above, we calculated the individual and total rate constants with TST considering Eckart tunneling effect in the temperature range of $300-2500 \mathrm{~K}$; the results are presented in Fig. 4 for the $\mathrm{C}_{2} \mathrm{H}_{5}+\mathrm{C}_{n} \mathrm{H}_{2 n+1} \mathrm{OH}(n=1,2)$ reactions and in 
Fig. S4 in the ESI for the $\mathrm{C}_{2} \mathrm{H}_{5}+\mathrm{C}_{n} \mathrm{H}_{2 n+1} \mathrm{OH}(\mathrm{n}=3,4)$ reactions. The branching ratios calculated from the individual and total rate constants for each channel are presented in Figs. 5 and S5 for the reactions of $\mathrm{C}_{2} \mathrm{H}_{5}$ with $\mathrm{C}_{n} \mathrm{H}_{2 n+1} \mathrm{OH}(\mathrm{n}=1,2)$ and $\mathrm{C}_{n} \mathrm{H}_{2 n+1} \mathrm{OH}(\mathrm{n}=3,4)$, respectively.

It can be seen in Fig. 4 and S4 that all the rate constants have positive temperature dependence reflecting the fact that each channel has prominent and distinct barrier energy. For the $\mathrm{C}_{2} \mathrm{H}_{5}+\mathrm{CH}_{3} \mathrm{OH}$ reaction, the rate constants for the substitution reactions via TS3 - TS6 is very much smaller than those for $\mathrm{H}$ abstraction via TS1 and TS2 for all the considered temperatures (see Figure 5a). For example, the values for the channels via TS1 and TS3 are $4.06 \cdot 10^{-16}$ and $1.70 \cdot 10^{-24}\left(\mathrm{~cm}^{3}\right.$ molecule $\left.\mathrm{s}^{-1}\right)$ at $1000 \mathrm{~K}$, respectively. Therefore, the branching ratios for the channels via TS3 - TS6 are very small with the highest value is only $\sim 4 \cdot 10^{-3}$ for the channel via TS4 at $2500 \mathrm{~K}$. This is because the barrier energies for these channels are much higher (> $27 \mathrm{kcal} / \mathrm{mol}$ ) than those for the $\mathrm{H}$-abstraction channels as discussed above. As a result, the $\mathrm{H}$-abstraction channels giving PR1 $\left(\mathrm{CH}_{3} \mathrm{O}+\mathrm{C}_{2} \mathrm{H}_{6}\right)$ and PR2 $\left(\mathrm{CH}_{2} \mathrm{OH}+\mathrm{C}_{2} \mathrm{H}_{6}\right)$ should be the major channels while the substitution channels giving PR3 - PR6 should be ignored in the $\mathrm{C}_{2} \mathrm{H}_{5}+$ $\mathrm{CH}_{3} \mathrm{OH}$ reaction. Our kinetics results show that the branching ratios for PR1 and PR2 channels are not much different in the considered temperatures; the values for PR1 are from 0.62 at $300 \mathrm{~K}$ to 0.32 at 2500 K. The temperature dependence of the total rate constant for the $\mathrm{C}_{2} \mathrm{H}_{5}+\mathrm{CH}_{3} \mathrm{OH}$ reaction can be expressed, in terms of three-parameters fits of the form $A T^{n} \exp (-E / T)$, as follows:

$k(\mathrm{~T})=1.31 \times 10^{40} \mathrm{~T}^{8.69} \exp (-2264.4 \mathrm{~K} / \mathrm{T})(\mathrm{T}=300-600 \mathrm{~K})$

$k(T)=2.11 \times 10^{25} \mathrm{~T}^{3.94} \exp (-5105.8 \mathrm{~K} / \mathrm{T})(\mathrm{T}=600-2500 \mathrm{~K})$

For the $\mathrm{C}_{2} \mathrm{H}_{5}+\mathrm{C}_{n} \mathrm{H}_{2 n+1} \mathrm{OH}(\mathrm{n}=2$ - 4) reactions, we did not calculate the rate constants for the substitution channels because of high barrier energies as discussed above. For the reaction of $\mathrm{C}_{2} \mathrm{H}_{5} \mathrm{OH}, \mathrm{the} \beta-\mathrm{H}$ abstraction channel via TS9 are about 2 orders lower than those for $\mathrm{a}-\mathrm{H}$ and $\mathrm{o}-\mathrm{H}$ abstraction channels via TS7 and TS8 at $300 \mathrm{~K}$ agreeing with the fact that the barrier energy at TS9 $(16.7 \mathrm{kcal} / \mathrm{mol})$ is higher than those at TS7 $(13.0 \mathrm{kcal} / \mathrm{mol})$ and TS8 $(12.6 \mathrm{kcal} / \mathrm{mol})$. However, the branching ratios for the three pair products PR7 $\left(\mathrm{C}_{2} \mathrm{H}_{5} \mathrm{O}+\mathrm{C}_{2} \mathrm{H}_{6}\right)$, PR8 $\left(\mathrm{CH}_{3} \mathrm{CHOH}+\mathrm{C}_{2} \mathrm{H}_{6}\right)$, and PR9 $\left(\mathrm{CH}_{2} \mathrm{CH}_{2} \mathrm{OH}+\mathrm{C}_{2} \mathrm{H}_{6}, 1.5 \mathrm{kcal} / \mathrm{mol}\right)$ via TS7, TS8, and TS9 are almost the same at high temperatures; at $2500 \mathrm{~K}$, the values for PR7, PR8, and PR9 are $0.31,0.39$, and 0.30 , respectively. For the reactions of $n / i-C_{3} \mathrm{H}_{7} \mathrm{OH}$ and n/s- $\mathrm{C}_{4} \mathrm{H}_{9} \mathrm{OH}$, one can see that the $\mathrm{a}-\mathrm{H}$ abstraction channels are dominant at $300 \mathrm{~K}$ due to the low barrier energies as discussed above. But their branching ratios decrease when temperature increases; all the products via $\mathrm{H}$-abstraction channels, therefore, become competitive. For example, at $2500 \mathrm{~K}$, for the reaction of $n-\mathrm{C}_{3} \mathrm{H}_{7} \mathrm{OH}$, the branching ratios of $\mathrm{o}-\mathrm{H}, \mathrm{a}-\mathrm{H}, \beta-\mathrm{H}$, and $\mathrm{y}-\mathrm{H}$ abstraction channels are $0.19,0.36,0.27$, and 0.18 , respectively. For the reaction of $\mathrm{i}-\mathrm{C}_{4} \mathrm{H}_{9} \mathrm{OH}$, Fig. $5 \mathrm{~S}$ show that the $\beta-\mathrm{H}$ abstraction channel is dominated at all the considered temperature range of $300-2500 \mathrm{~K}$ due to its lowest barrier energy. Its branching ratio also decreases when temperature increases but it is still highest at $2500 \mathrm{~K}$ with the value of 0.431 . For the reactions of $\mathrm{t}-\mathrm{C}_{4} \mathrm{H}_{9} \mathrm{OH}$, there are two $\mathrm{H}$ abstraction channels at o- $\mathrm{H}$ and $\beta-\mathrm{H}$; the first channel is dominated at $300 \mathrm{~K}$ with the branching ratio value of 0.761 but decreases to 0.297 at $2500 \mathrm{~K}$. 
For convenient modeling applications, the temperature dependence of the individual reaction rate constants for the title reactions given in terms of three parameters fits the form $A T^{\mathrm{n}} \exp (-\mathrm{E} / \mathrm{T})$ expressions in the temperature range of $300-1000 \mathrm{~K}$ are summarized in Table II.

\section{Conclusions}

Mechanism and kinetics for the reactions of $\mathrm{C}_{2} \mathrm{H}_{5}+\mathrm{C}_{n} \mathrm{H}_{2 n+1} \mathrm{OH}(\mathrm{n}=1-4)$ have been investigated for the first time by both quantum-chemical and TST calculations. The quantum-chemical results show that the tile reactions can mainly undergo $\mathrm{H}$-abstraction with barrier energies of $10.4-16.4 \mathrm{kcal} / \mathrm{mol}$. The rate constants and product branching ratios have been calculated for the temperature range of $300-2500 \mathrm{~K}$. The predicted rate constants and branching ratios for the $\mathrm{H}$-abstraction reactions have been calculated using the transition state theory with quantum-mechanical tunneling corrections for the temperature range. The kinetics results show that all the rate constants increase when temperature increases. For the $\mathrm{C}_{2} \mathrm{H}_{5}+\mathrm{i}-\mathrm{C}_{4} \mathrm{H}_{9} \mathrm{OH}$ reaction, the $\beta-\mathrm{H}$ abstraction channels via barrier energy of $11.7 \mathrm{kcal} / \mathrm{mol}$ giving $\left(\mathrm{CH}_{3}\right)_{2} \mathrm{CCH}_{2} \mathrm{OH}+\mathrm{C}_{2} \mathrm{H}_{6}$ are dominated at all the considered temperatures. For the $\mathrm{C}_{2} \mathrm{H}_{5}+\mathrm{t}-\mathrm{C}_{4} \mathrm{H}_{9} \mathrm{OH}$ reaction, there are two channels including $\mathrm{o}-\mathrm{H}$ and $\beta-\mathrm{H}$ abstractions via barrier energy of 12.8 and 15.4 $\mathrm{kcal} / \mathrm{mol}$, respectively, in which the latter is more favor at high temperatures $(>1500 \mathrm{~K})$. For others, the $\mathrm{a}-\mathrm{H}$ abstraction channels are dominated at temperatures below $500 \mathrm{~K}$ but all of the products via $\mathrm{H}$ abstraction channels can contribute at a high-temperature range of $2000-2500 \mathrm{~K}$. The temperature dependence of the individual reaction rate constants for the title reactions is provided for further modeling applications. Our geometries and heats of reaction are in good agreement with available experimental data.

\section{Declarations}

\section{Acknowledgements}

This research is funded by Vietnam National Foundation for Science and Technology Development (NAFOSTED) under grant number 104.06-2018.33.

\section{Author Contributions}

All authors contributed to the conceptualization and realization of the study. Trong-Nghia Nguyen carried out the computations and wrote the first draft. Writing review and editing by Hue Minh Thi Nguyen and revision was done by her with help of the other authors. All authors have read and agree to the published version of the manuscript.

\section{Supplementary Information}

The supplement related to this article is available online and contains extended information on the calculations.

\section{Conflict of Interest}


The authors declare no conflict of interest.

\section{References}

1. Aronowitz D, Naegeli DW, Glassman I (1977) J Phys Chem 81:2555. https://doi.org/10.1021/j100540a037

2. Wu CW, Lee YP, Xu S, Lin MC (2007) J Phys Chem A 111:6693. doi: 10.1021/jp068977z

3. Poh CH, Poh CK (2017) Adv Aerosp Sci Tech 2:23. doi: 10.4236/aast.2017.23003

4. Qian Y, Guo J, Zhang Y, Tao W, Lu X (2018) Appl Therm Eng 144:126. https://doi.org/10.1016/j.applthermaleng.2018.08.044

5. Mertens LA, Manion JA (2021) Int J Chem Kinet 53:95. DOI: 10.1002/kin.21428

6. Kumar K, Zhang Y, Sung CJ, Pitz WJ (2015) Combust Flame 162:2466. https://doi.org/10.1016/j.combustflame.2015.02.014

7. Rosado-Reyes CM, Tsang W (2013) J Phys Chem A 117:10170. https://doi.org/10.1021/jp404877t

8. Cai J, Yuan W, Ye L, Cheng Z, Wang Y, Zhang L, Zhang F, Li Y, Qi F (2013) Combust. Flame 160, 1939

9. http://dx.doi.org/10.1016/j.combustflame.2013.04.010

10. Heyne JS, Dooley S, Dryer FL (2013) J Phys Chem A 117:8997. https://doi.org/10.1063/1.1742240

11. Venkateswarlu P, Gordy W (1955) J Chem Phys 23:1200. https://doi.org/10.1063/1.1742240

12. Shimanouchi T Tables of molecular vibrational frequencies. Consolidated Volume 1, NSRDS NBS-39

13. Coussan S, Bouteiller Y, Perchard JP, Zheng WQ (1998) J Phys Chem A 102:5789. https://doi.org/10.1021/jp9805961

14. Aronowitz D, Naegeli DW, Glassman I (1977) J Phys Chem 81:2555. https://doi.org/10.1021/j100540a037

15. Wu CW, Matsui H, Wang NS, Lin MC (2011) J Phys Chem A 115:8086. https://doi.org/10.1021/jp202001q

16. Barnard JA, Hughes HWD (1960) Trans Faraday Soc 56:64. https://doi.org/10.1039/TF9605600064

17. J. A. Barnard, The pyrolysis of isopropanol.Trans. Faraday Soc.5672-79. https://doi.org/10.1039/TF9605600072

18. Barnard JA (1957) Trans Faraday Soc 53:1423. https://doi.org/10.1039/TF9575301423

19. Gu X, Huang Z, Wu S, Li Q (2010) Combust. Flame 157, 2318. https://doi.org/10.1016/j.combustflame.2010.07.003

20. Grana R, Frassoldati A, Faravelli T, Niemann U, Ranzi E, Seiser R, Cattolica R, Seshadri K (2010) Combust Flame 157:2137. https://doi.org/10.1021/jp806464p

21. Lee PF, Matsui H, Xu DW, Wang NS (2013) J Phys Chem A 117:525. https://doi.org/10.1021/jp309745p

22. Xu ZF, Park J, Lin MC (2004) J Chem Phys 120:6593. https://doi.org/10.1063/1.1650832 
23. Moss JT, Berkowitz AM, Oehlschlaeger MA, Biet J, Warth V, Glaude PA, Battin-Leclerc F (2008) J Phys Chem A 112:10843. https://doi.org/10.1021/jp806464p

24. Heyne JS, Dooley S, Dryer FL (2013) J Phys Chem A 117:8997. https://doi.org/10.1021/jp404143f 25. Lendvay G, Berces T, Marta F (1997) J Phys Chem A 101:1588. https://doi.org/10.1021/jp963188a 26. Jodkowski JT, Rayez MT, Rayez JC, Bérces T, Dóbé. S (1999) J Phys Chem A 103:3750. https://doi.org/10.1021/jp984367q

27. Xu S, Lin MC (2007) Proc. Combust. Inst. 31, 159. https://doi.org/10.1016/j.proci.2006.07.132

28. Galano A, Alvarez-Idaboy JR, Bravo-Perez G, Ruiz-Santoyo ME (2002) Phys Chem Chem Phys 4:4648. https://doi.org/10.1039/B205630E

29. Garzón A, Cuevas CA, Ceacero AA (2006) J Chem Phys 125:104305. https://doi.org/10.1063/1.2244556

30. Shannon RJ, Cossou C, Loison JC, Caubet P, Balucani N, Seakins PW, Wakelam V, Hickson KM (2014) RSC Adv 4:26342. https://doi.org/10.1039/C4RA03036B

31. Huang CK, Xu ZF, Nakajima M, Nguyen HMT, Lin MC, Tsuchiya S, Lee YP (2012) J Chem Phys 137:164307. https://doi.org/10.1063/1.4759619

32. Taatjes CA, Christensen LK, Hurley MD, Wallington TJ (1999) J Phys Chem A 103:9805. https://doi.org/10.1021/jp992465I

33. Yasunaga K, Gillespie F, Simmie JM, Curran HJ, Kuraguchi Y, Hoshikawa H, Yamane M, Hidaka Y (2010) J Phys Chem A 114:9098. https://doi.org/10.1021/jp104070a

34. Starik AM, Pelevkin AV, Titova NS (2017) Combust Flame 176:81. http://dx.doi.org/10.1016/j.combustflame.2016.10.005

35. Kaiser EW (2002) J Phys Chem A 106:7, 1256. https://doi.org/10.1021/jp013089j

36. Ludwig W, Brandt B, Friedrichs G, Temps F (2006) J Phys Chem A 110:3330. https://doi.org/10.1021/jp0557464

37. Pan YR, Tang YZ, Sun JY, Sun H, Wang RS (2011) Int J Quantum Chem 111:2922. https://doi.org/10.1155/2018/3036791

38. Zhang HX, Ahonkhai SI, Back MH (1989) Can J Chem 67:1541. https://doi.org/10.1139/v89-235 39. Yan T, Hase WL, Doubleday C (2004) J Chem Phys 120:9253. http://dx.doi.org/10.1063/1.1705574 40. Lee C, Yang W, Parr RG (1988) Phys Rev B 37:785. https://doi.org/10.1103/PhysRevB.37.785

41. Raghunath P, Nghia NT, Lin MC (2014) Adv Quantum Chem 69:253. https://doi.org/10.1016/B978-012-800345-9.00007-6

42. Purvis GD III, Bartlett RJ (1982) J. Chem. Phys. 76, 1910. https://doi.org/10.1063/1.443164

43. Raghavachari K, Trucks GW, Pople JA, Head-Gordon MA (1989) Chem Phys Lett 157:479-483. https://doi.org/10.1016/S0009-2614(89)87395-6

44. Frisch MJ, Trucks GW, Schlegel HB, Scuseria GE, Robb MA, Cheeseman JR, Scalmani G, Barone V, Mennucci B, Petersson GA, Nakatsuji H, Caricato M, Li X, Hratchian HP, Izmaylov AF, Bloino J, Zheng 
G, Sonnenberg JL, Hada M, Ehara M, Toyota K, Fukuda R, Hasegawa J, Ishida M, Nakajima T, Honda Y, Kitao O, Nakai H, Vreven T, Montgomery JA Jr, Peralta JE, Ogliaro F, Bearpark M, Heyd JJ, Brothers E, Kudin KN, Staroverov VN, Keith T, Kobayashi R, Normand J, Raghavachari K, Rendell A, Burant JC, lyengar SS, Tomasi J, Cossi M, Rega N, Millam JM, Klene M, Knox JE, Cross JB, Bakken V, Adamo C, Jaramillo J, Gomperts R, Stratmann RE, Yazyev O, Austin AJ, Cammi R, Pomelli C, Ochterski JW, Martin RL, Morokuma K, Zakrzewski VG, Voth GA, Salvador P, Dannenberg S, Dapprich AD, Daniels O, Farkas JB, Foresman, Fox (2013) Gaussian 09, revision D.01, Gaussian, Inc., Wallingford, CT

45. Eyring $H$ (1935) J Chem Phys 3:107. https://doi.org/10.1063/1.1749604

46. Eckart C (1930) Phys Rev 35:1303. https://doi.org/10.1103/PhysRev.35.1303

47. Barker JR, Ortiz NF, Preses JM, Lohr LL, Maranzana A, Stimac PJ, Nguyen TL, Kumar TJD (2014) MultiWell Programe Suite User Manual, v. 2014.1, University of Michigan, US

48. Jackels CF (1982) J Chem Phys 76:505-515. https://doi.org/10.1063/1.442752

49. Herzberg G (1966) Electronic spectra and electronic structure of polyatomic molecules. Van Nostrand, New York

50. Durig JR, Jin Y, Phan HV, Liu J, Durig DT (2002) Struct Chem 13:1.

https://doi.org/10.1023/A:1013410428690

51. Coussan S, Bouteiller Y, Perchard JP, Zheng WQ (1998) J Phys Chem A 102:5789. https://doi.org/10.1021/jp9805961

52. Hellwege KH, Hellwege AM (eds) (1976) Landolt-Bornstein: Group II: atomic and molecular physics volume 7: structure data of free polyatomic molecules. Springer-Verlag, Berlin

53. Huber KP, Herzberg G (1979) Molecular spectra and molecular structure. IV. constants of diatomic molecules. Van Nostrand Reinhold Co.

54. Kuchitsu(K (ed) (1998) Structure of free polyatomic molecules - basic data. Springer, Berlin

55. Gurvich LV, Veyts IV, Alcock CB (1989) Thermodynamic properties of individual substances, fouth edition. Hemisphere Pub. Co., New York

56. Ruscic B, Boggs JE, Burcat A, Csaszar AG, Demaison J, Janoschek R, Martin JML, Morton ML, Rossi MJ, Stanton JF, Szalay PG, Westmoreland PR, Zabel F, Berces T (2005) J Phys Chem Ref Data 34:573. https://doi.org/10.1063/1.1724828

57. Cox JD, Wagman DD, Medvedev VA (1989)CODATA key values for thermodynamics, Hemisphere, New York

58. Frenkel M, Marsh KN, Wilhoit RC, Kabo GJ, Roganov GN (1994) Thermodynamics of organic compounds in the gas state, Thermodynamics research center, College Station, TX

59. Berkowitz J, Ellison GB, Gutman D (1994) J Phys Chem 98:2744. https://doi.org/10.1021/j100062a009

\section{Figures}




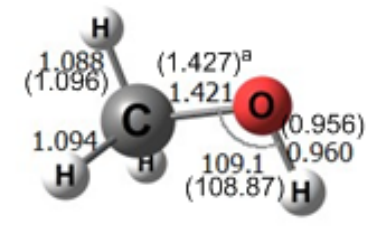

$\mathrm{CH}_{3} \mathrm{OH}$

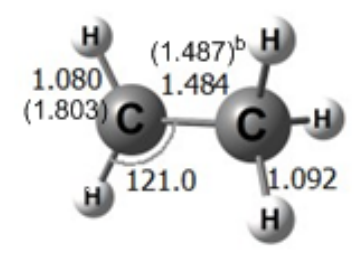

$\mathrm{C}_{2} \mathrm{H}_{5}$

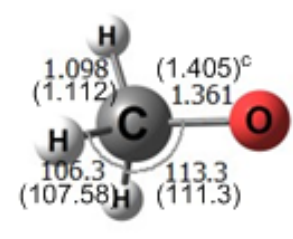

$\mathrm{CH}_{3} \mathrm{O}$

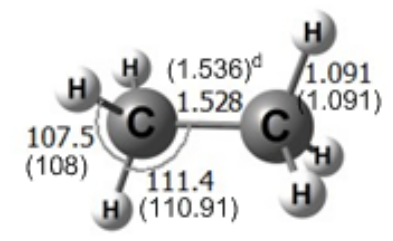

$\mathrm{C}_{2} \mathrm{H}_{6}$

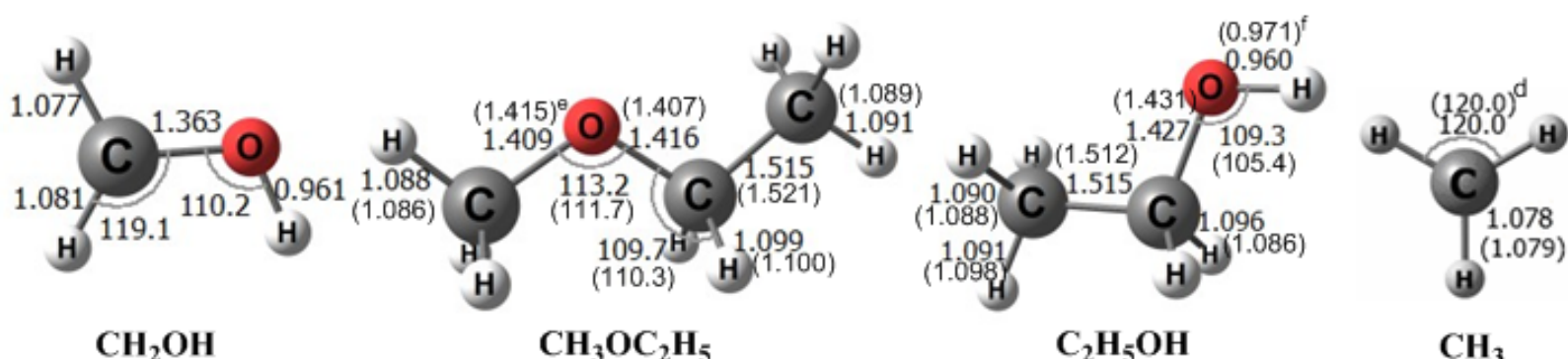

$\mathrm{CH}_{2} \mathrm{OH}$

$\mathrm{CH}_{3} \mathrm{OC}_{2} \mathrm{H}_{5}$

$\mathrm{C}_{2} \mathrm{H}_{5} \mathrm{OH}$

$\mathrm{CH}_{3}$

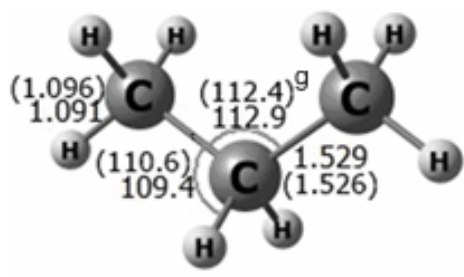

$\mathrm{C}_{3} \mathrm{H}_{8}$

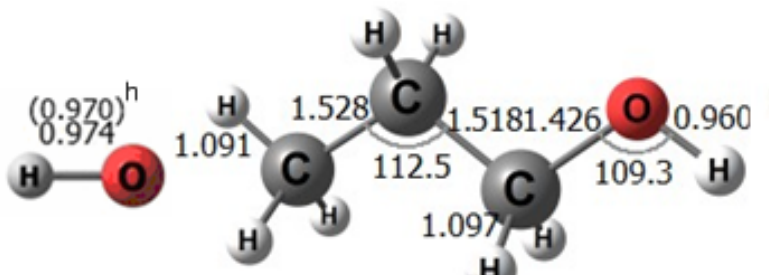

H)

OH

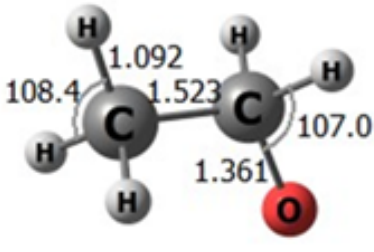

$\mathrm{C}_{2} \mathrm{H}_{5} \mathrm{O}$

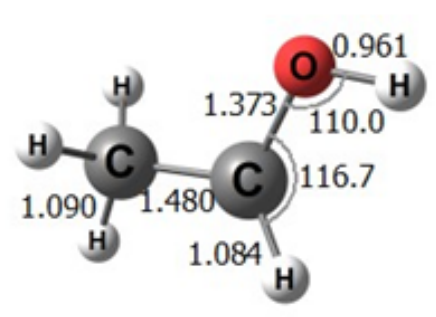

$\mathrm{CH}_{3} \mathrm{CHOH}$

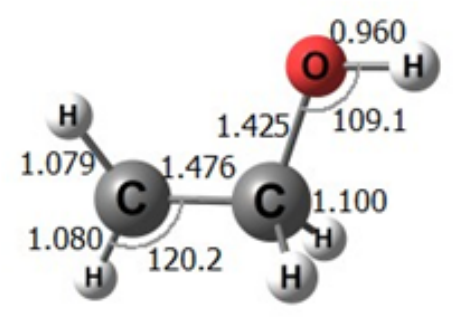

$\mathrm{CH}_{2} \mathrm{CH}_{2} \mathrm{OH}$
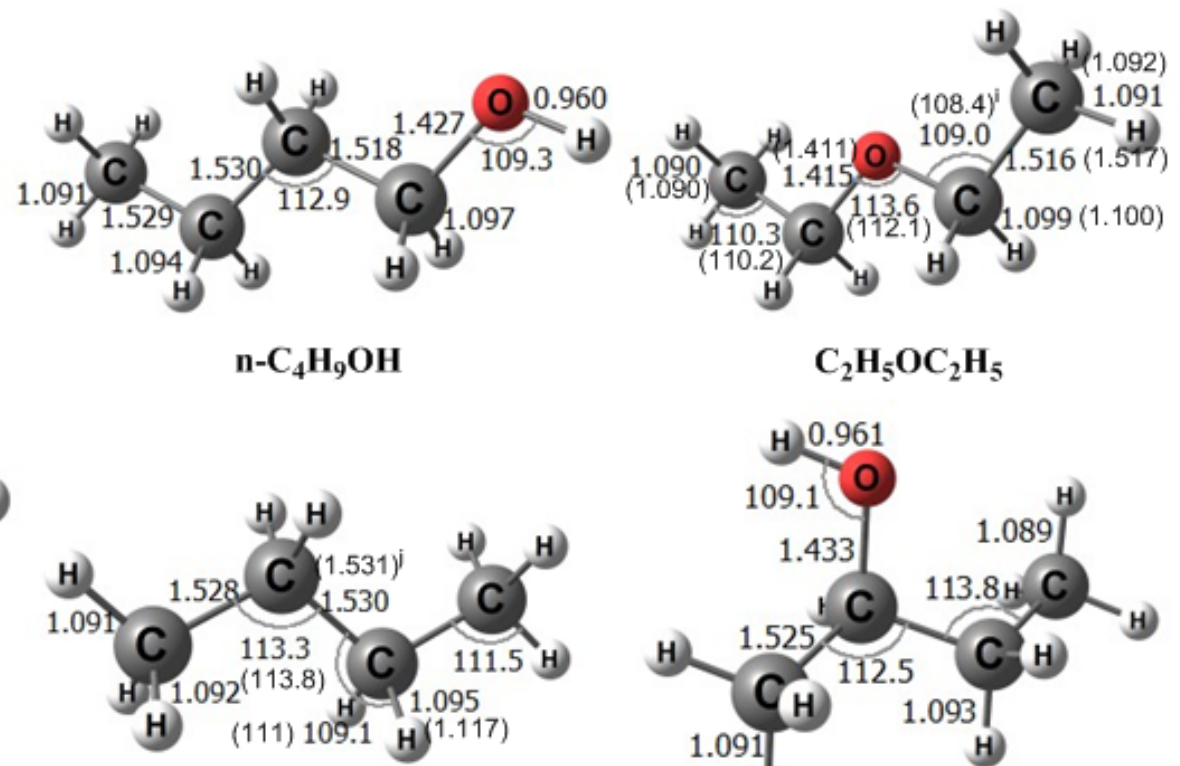

n- $\mathrm{C}_{4} \mathrm{H}_{10}$

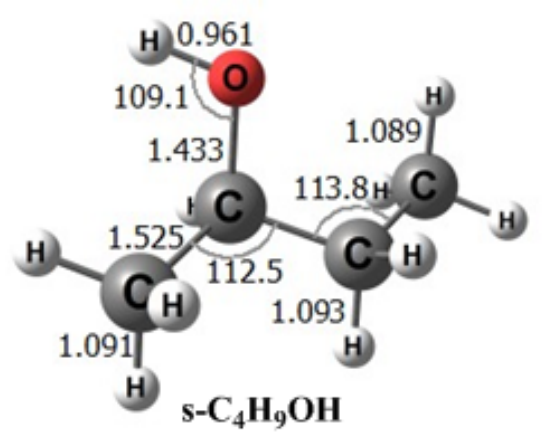

\section{Figure 1}

Geometries of the reactants and products related to the $\mathrm{C}_{2} \mathrm{H}_{5}+\mathrm{C}_{n} \mathrm{H}_{2 n+1} \mathrm{OH}(n=1,2)$ reactions. ${ }^{a-j}$ The values in the parenthesis are from the literature. [10,36,47-53] 


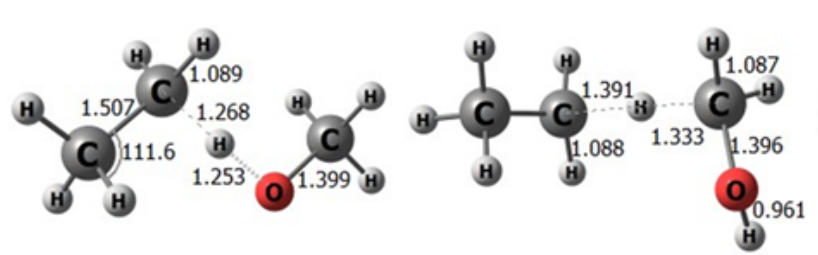

TS1

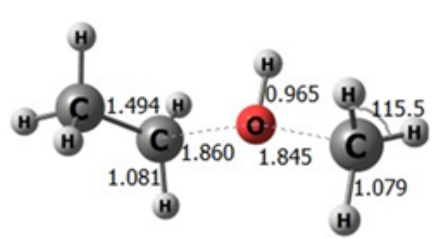

TS4

TS2

TS5

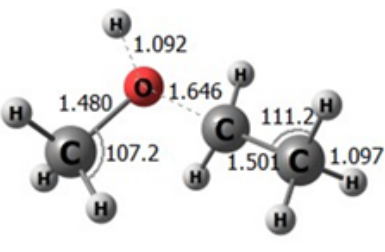

TS3

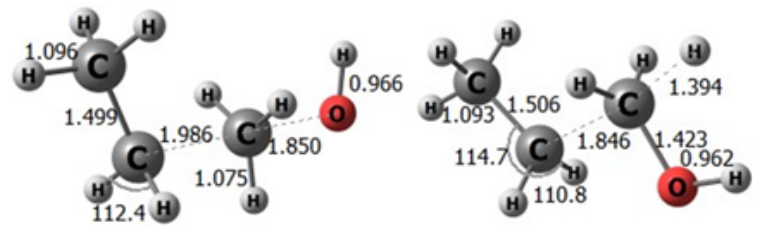

TS6
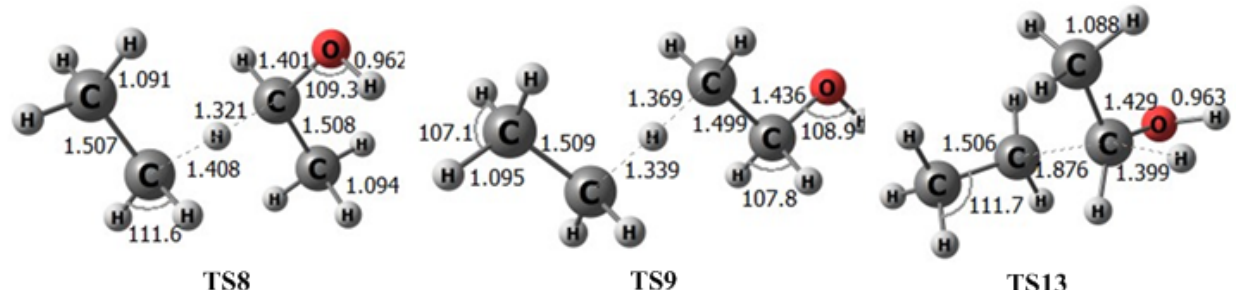

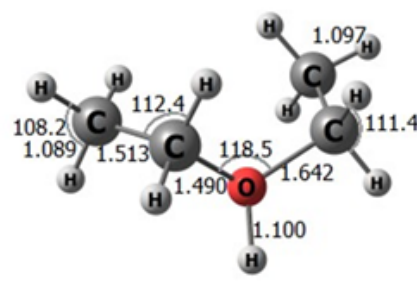

TS10

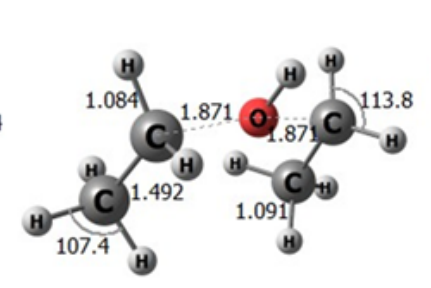

TS11

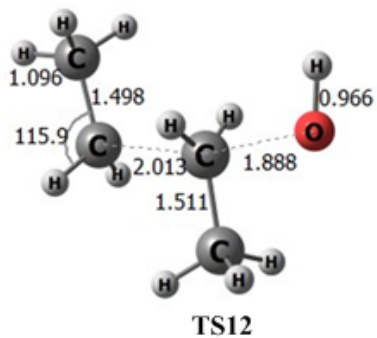

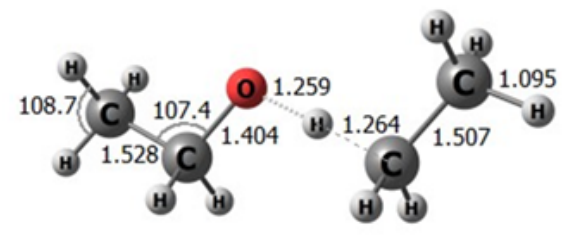

TS7

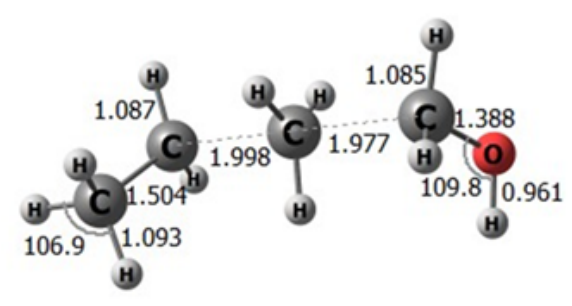

TS15

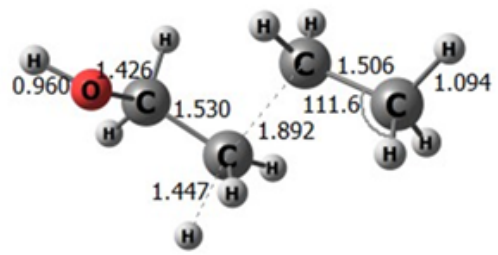

TS14

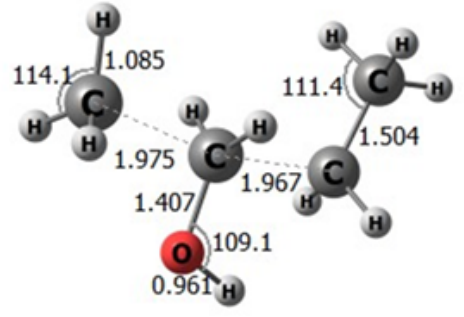

TS16

\section{Figure 2}

Geometries of the transition states related to the $\mathrm{C}_{2} \mathrm{H}_{5}+\mathrm{C}_{n} \mathrm{H}_{2 n+1} \mathrm{OH}(n=1,2)$ reactions. 

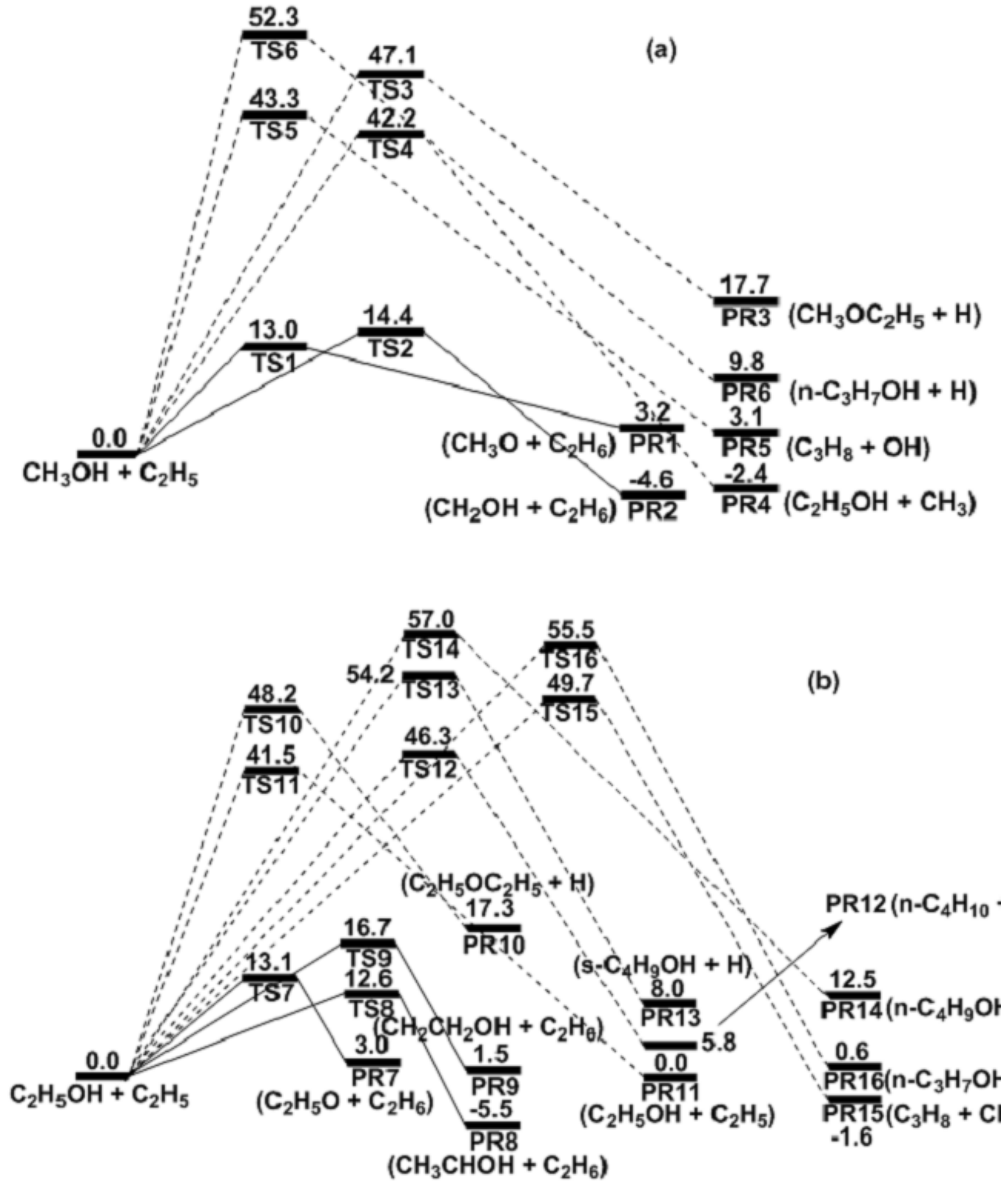

Figure 3

Potential energy profiles for the $\mathrm{C}_{2} \mathrm{H}_{5}+\mathrm{C}_{n} \mathrm{H}_{2 n+1} \mathrm{OH}(n=1,2)$ reactions. 

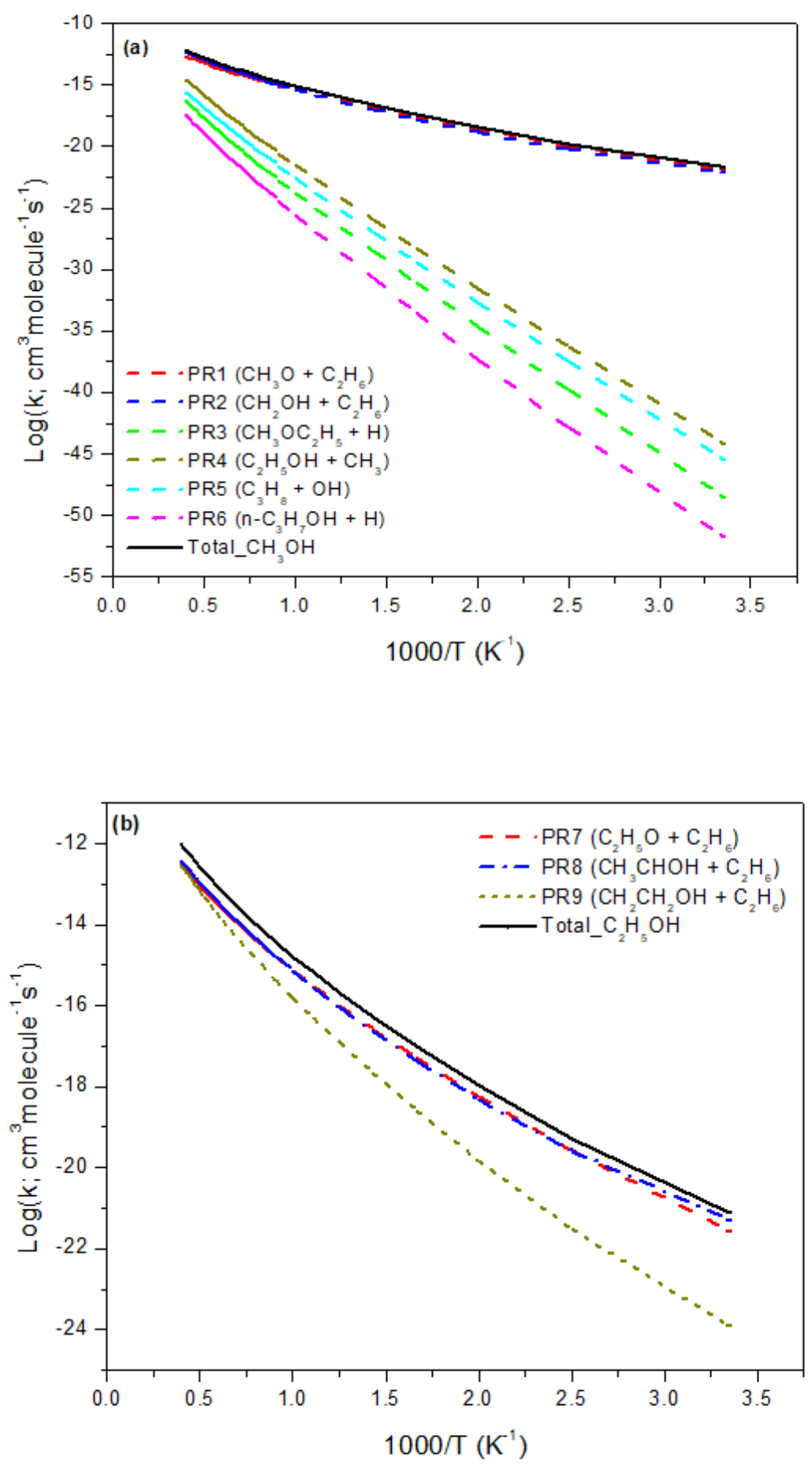

Figure 4

Arrhenius plots of bimolecular reactions of the $\mathrm{C}_{2} \mathrm{H}_{5}+\mathrm{C}_{n} \mathrm{H}_{2 n+1} \mathrm{OH}(n=1,2)$ reactions. 

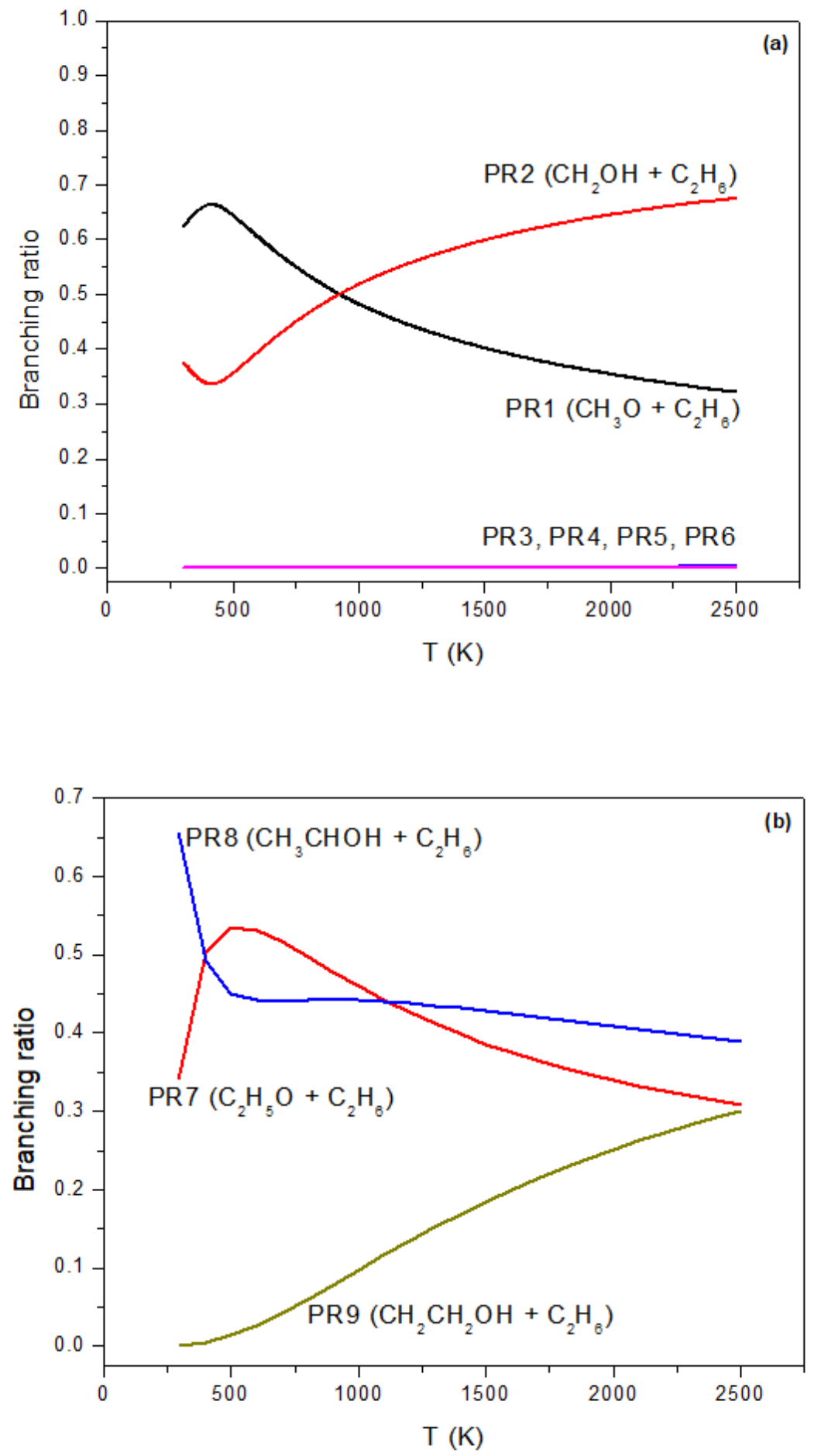

Figure 5

Branching ratios for the $\mathrm{C}_{2} \mathrm{H}_{5}+\mathrm{C}_{n} \mathrm{H}_{2 n+1} \mathrm{OH}(n=1,2)$ reactions.

\section{Supplementary Files}

This is a list of supplementary files associated with this preprint. Click to download. 
- SIC2H5ancol.doc

Page 20/20 